local councils in a selected region in either Kenya or Ghana, for which the Centre has been awarded a grant by the Social Science Research Council (U.K.) for a research fellowship.

\title{
SCOLMA: Area Specialization Plan
}

The Standing Conference on Library Materials on Africa (SCOLMA) has initiated a cooperative scheme whereby member libraries have assumed responsibility for obtaining current material from a particular country or region. Pamphlets and government publications are included within the scope of the scheme as well as commercially published books, but periodicals and newspapers are to be considered separately when the surveys of holdings have been completed. Participating libraries are not obliged to buy all the publications from the area if they can be located elsewhere; the holdings of libraries which specialize in certain disciplines rather than in regions will complement the area collections. It is intended, however, that the specializing libraries should build up strong collections of their own, and become centres for bibliographical information.

The scheme came into effect on I January 1966. Co-operating libraries have been asked to compile annual statistics of acquisitions, as these will give some indication of the efficacy of the project, and provide useful information regarding the volume of current publication in African countries.

A list of libraries participating in the scheme and further information regarding this project and SCOLMA's other activities may be obtained from the Secretary: Mrs. Valerie Bloomfield, Librarian, Institute of Commonwealth Studies, 27 Russell Square, London, W.C. I.

\section{Faculté de Droit et des Sciences Economiques de Paris}

La Faculté de Droit et des Sciences Économiques de Paris vient de créer une série 'Afrique" dans la collection de ses 'Travaux et Mémoires'. Le premier volume, intitulé Essais sur l'Économie de l'Algérie nowvelle, comprend trois mémoires: F. d'Arcy ('L'administration communale dans les communes rurales du Département de Constantine '); A. Krieger (' Les prémices d'une réforme agraire '); A. Marill (' L'expérience d'autogestion industrielle '); Le second volume portera sur les forces politiques en Afrique Noire; J.-L. Alibert (' L'opposition en Afrique Noire '); B. Traore ('L'évolution des partis politiques en Sénégal depuis $1948^{\prime}$ '); M. Lo (' L'union progressiste sénégalaise ').

\section{Etudes Africanistes dans les Facultés et dans les Instituts de l'Université de Dakar}

LA Faculté des Lettres et Sciences humaines organise un cycle de conférences et de cours - dont certains sont publics - qui prenne l'Afrique en général et plus spécialement l'Afrique Noire comme thème, et publie elle-même livres et articles largement diffusés dans le monde entier, notamment parmi les Africanistes. Le domaine où cette action se fait plus spécialement sentir comporte: la littérature négro-africaine; l'histoire, le protohistoire et l'archéologie; l'enseignement des langues et la linguistique; langues africaines (Wolof notamment) et linguistique africaine. Dans l'Institut Fondamental d'Afrique Noire (IFAN) le département archéologie-préhistoire prépare le Congrès international de préhistoire, qui doit se tenir à Dakar en 1967. Un laboratoire de radiocarbone va être terminé en 1966, unique en son genre en Afrique.

\section{Syracuse University Program of East Africa Studies: Occasional Papers}

These Occasional Papers are designed to circulate research material of faculty and graduate students of the Program of East African Studies of Syracuse University. Nineteen papers 